\title{
TRADÍCIONÁLIS TERMÉKEK EMOCIONÁLIS MEGKÖZELÍTÉSBEN
}

\author{
${ }^{1}$ Dr. Ferencz Árpád PhD- ${ }^{2}$ Dr. Nótári Márta $\mathrm{PhD}$ \\ ${ }^{1}$ föiskolai tanár, Kecskeméti Föiskola Kertészeti Föiskolai Kar, Kecskemét \\ ${ }^{2}$ föiskolai docens, Kecskeméti Föiskola Kertészeti Főiskolai Kar, Kecskemét
}

SUMMARY

Traditional Hungarian foods get successfully to consumers if these products are sold on a special market. In our research we set a hypothesis that the decisions, what traditional food consumers make, are based on imperfect information. Place of purchase is an influential factor. Based on this assumption we examined the followings in a questionnaire survey: Where do customers like to buy these products?, Is there an appropriate market for these products?, What are the attributes of this market?

The basic aim of our research was to know how special quality single and differentiated products can stay safely on the market. Consumer segmentation seemed to be a good way to know this, but even some members of the same segment can have different purchase decisions. Personal life style determines this deviation. The subject of our research was to see how effective segmentation influences the dynamics of consumer product choice.

Kulcsszavak: tradicionális élelmiszerek, marketing, vásárlói értékítélet

\section{BEVEZETÉS}

Az egyik fö kihívás a differenciálható termékek esetén, hogyan lehet nyereségesen piacon maradni. Ehhez a vásárlók szegmentálása jónak tünik, de megfigyelték, hogy a hasonló demográfiai helyzetben levők különféleképpen viselkednek vásárlási döntéseikben. Az eltérés fő meghatározója az egyén stílusa, önbecsülése, ami nem korrelál a demográfiai tényezökkel. Az értékítélet fontosabbnak tünik, mint a demográfiai helyzet. Egy hatékony szegmentálás ötvözni képes a termékkategóriára sajátosan jellemző fogyasztói dinamikát a szintén termékspecifikus motivációs dinamikával. E két módszer együttes alkalmazása fokozhatja a stratégiai marketing-,,intelligenciát”, amely igencsak szükséges napjainkban a régiós termékek nyereséges piacon tartásában. Kutatásunkban azt vizsgáltuk, hogy egy hatékony szegmentálás miként befolyásolja a fogyasztók termékválasztási dinamikáját.

\section{ANYAG ÉS MÓDSZER}

\subsection{KUTATÁS HÁTTERE}

2010-2011. évben primer kutatásokat végeztünk a kertészeti és élelmiszeripari hungarikumok fogyasztók fogyasztói magatartásának és életstílusának elemzésére. A mintákat a Központi Statisztikai Hivatal adatai alapján súlyozottan gyüjtöttük. A programunkba bevittünk 1956 kérdöiv adatait és feltételeket adtunk meg az SPSS programnak (select variable). Ez lehetőséget nyújt arra, hogy a megadott feladattömbböl kiszürje a nem szükséges adatokat. Így az alapsokaság összetétele megfelelt a KSH népesség nyilvántartás összetételének. A mintánk így közel reprezentatív lett, azaz 1304 minta elemszám alapján az egész magyar népességre következtetéseket tudtunk levonni.

\subsection{A VÁLTOZÓK STRUKTÚRÁJÁNAK VIZSGÁLATA FAKTORANALÍZISSEL}

A változók számának csökkentése azt jelenti, hogy a statisztikai mintában lévő információ lehetőleg kis csökkentésével ugyanazt a jelenséget kevesebb változóval írjuk le. Ennek egyik módszere a faktoranalízis, mely során az elemek közötti függőség felderíthető úgy, hogy az eredeti változók helyett hipotetikus változókat, ún. faktorokat határoztunk meg. 
A faktoranalízis során a faktorok meghatározásakor a vizsgált változók korrelációs mátrixából indulunk ki. Amelyik változó nem korrelál más változókkal, nagy valószínűséggel önálló faktorral rendelkezik. Ha viszont két vagy több változó között szoros korreláció van, akkor feltételezhető, hogy egy vagy néhány közös faktorral rendelkeznek. Faktoranalízis során a faktorsúlyok mátrixát kerestük.

\section{EREDMÉNYEK}

3.1. A tradícionális élelmiszereket fogyasztók életstílus vizsgálata

Életünk során nap, mint nap hozunk vásárlói döntéseket, érvényesítve elsősorban saját elképzeléseinket. Ha a folyamatot mélyebben vizsgáljuk, akkor kiderül, hogy választásaink, elhatározásaink mögött bonyolult pszichológiai és szociológiai döntések húzódnak meg. Az utóbbi évtizedben a fogyasztói magatartás vizsgálata és a pszichológia egyre inkább összekapcsolódott, mert az életstílus kutatások eredménye felhasználható a termékek megfelelő pozicionálásánál vagy reklámüzenetek tervezésénél.

\section{1. ábra: Életstílus vizsgálat arbitrális faktor elemzéssel}

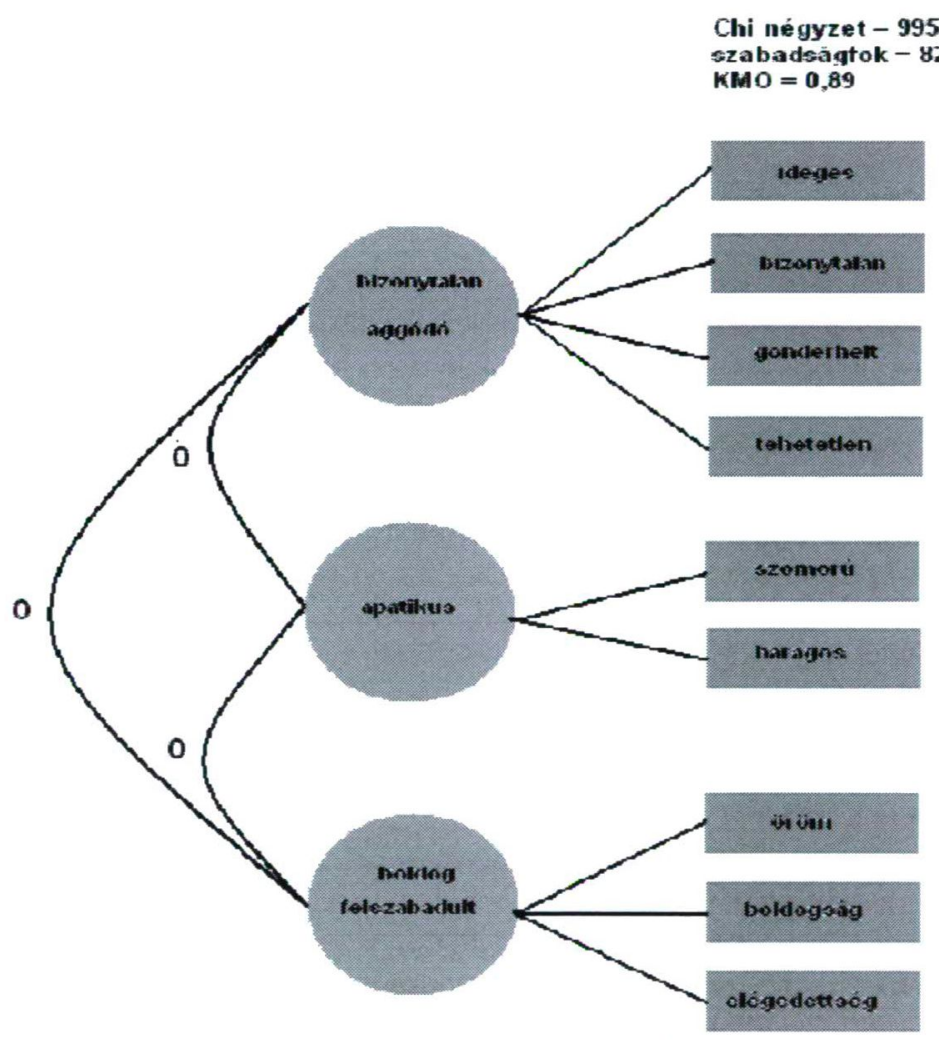

Forrás: Saját szerkesztés, 2012

Az 1. ábra mindkét oszlopában megtalálható a bizonytalanság, frusztráltság érzése. A pszichológia is alátámasztja azt az érzést, hogy a jövő mindig bizonytalan. Ezzel együtt kell élni és szembenézni a váratlan eseményekkel. Ez az érzés megjelent a mélyinterjúk készítésekor és a megkérdezéses kutatások értékelése során is. A bizonytalansági érzés csökkenhet a nagyobb kockázatvállalási készség kialakítása, a tolerancia és a rugalmasabb szabályok alkalmazása során. 


\subsection{Személyiség vizsgálat}

A személyiség-vizsgálati módszerek kialakulását az az igény tette szükségszerủvé, hogy a marketing kutatók is egyrészt meg akarták ismerni az egyéni különbségeket létrehozó belső tartalmakat (élményszinten és a viselkedés szintjén egyaránt), másrészt pedig számos esetben meg akarták határozni a várható viselkedés megjelenési valószínüségeit, okát, kialakulásának hátterét. A személyiség, a gondolkodás, az érzelmek és a viselkedés azon megkülönböztető mintáit jelenti, amelyek az egyén személyes stílusát meghatározzák, és a környezettel való interakcióit befolyásolják.

\section{2. ábra: A válaszadók szegmentációs csoportjai}

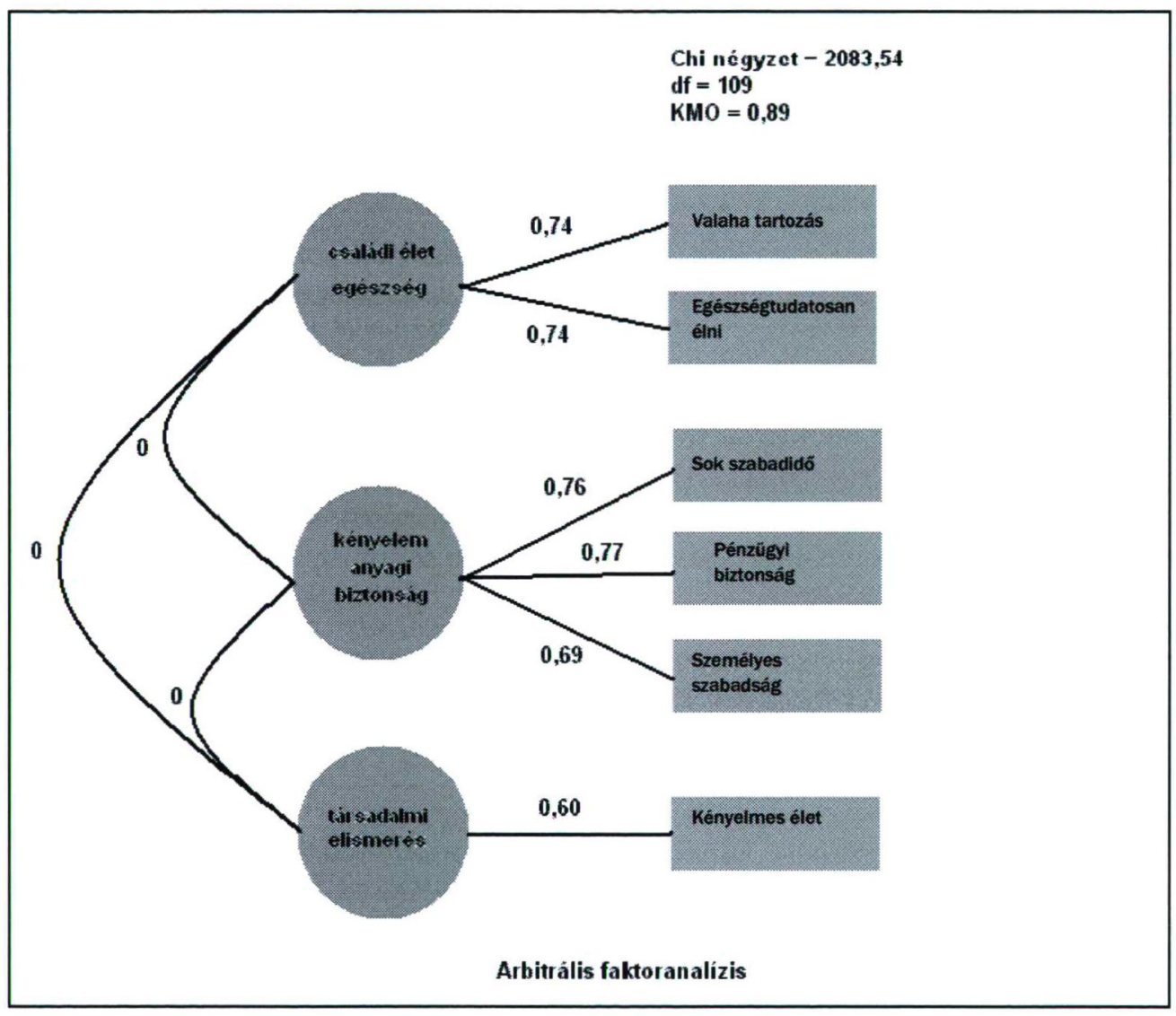

Forrás: Saját szerkesztés, 2012

Attitủd állítások alapján faktoranalízissel hoztuk létre szegmentációs csoportjainkat (2. ábra). Az állításokra adott válaszok alapján jelenítettük meg a háttérváltozókat. Ezt azért tartottuk fontosnak, mert az életstílus, az értékrend maghatározza a fogyasztói- és vásárlói magatartás tipikus formáit. Összefüggnek a termék- és márkaválasztással és a marketing kommunikáció iránti nyitottsággal. Ennek ismerete lehetővé teszi a fogyasztók számára értéket jelentő terméktulajdonságok ajánlását. Ebben az esetben ez azért fontos, mert az egyedi, tradicionális termékeket fogyasztók a helyi ízeket, a sajátos minőséget pluszként értelmezik és befolyásolják a termékekhez való viszonyulásukat. 


\subsection{A MEGKÉRDEZETTEK ÉRTÉKRENDJÉNEK VIZSGÁLATA}

A kérdőívben állításokat adtunk meg a válaszadóknak. A 3. ábrán azt láthatjuk, hogy a kérdésekre adott válaszok hogyan függnek össze. A sokdimenziós térben a válaszok, mint pontok jelennek meg, amelyek távolságáról, szórtságáról vagy csoportosulásáról következtetéseket lehet levonni a vásárlói illetve a fogyasztói magatartásra. Ábránkon az értékek között jelentős szóródás figyelhető meg. Az emberi kapcsolatok és a boldogság érzése pontjai viszonylag közel pozícionáltak. Ezek az értékek meghatározó szerepet tölthetnek be a fogyasztás folyamatában. Feltételezhető, hogy az a vásárló, akinek ezek az értékek fontosak pozitív attitủddel fordul a hagyományos, régiós termékek felé.

Az összefüggést a 3. ábra és a hozzá kapcsolódó táblázat mutatja be.

3. ábra: A megkérdezettek körében leginkább elérni kívánt célok

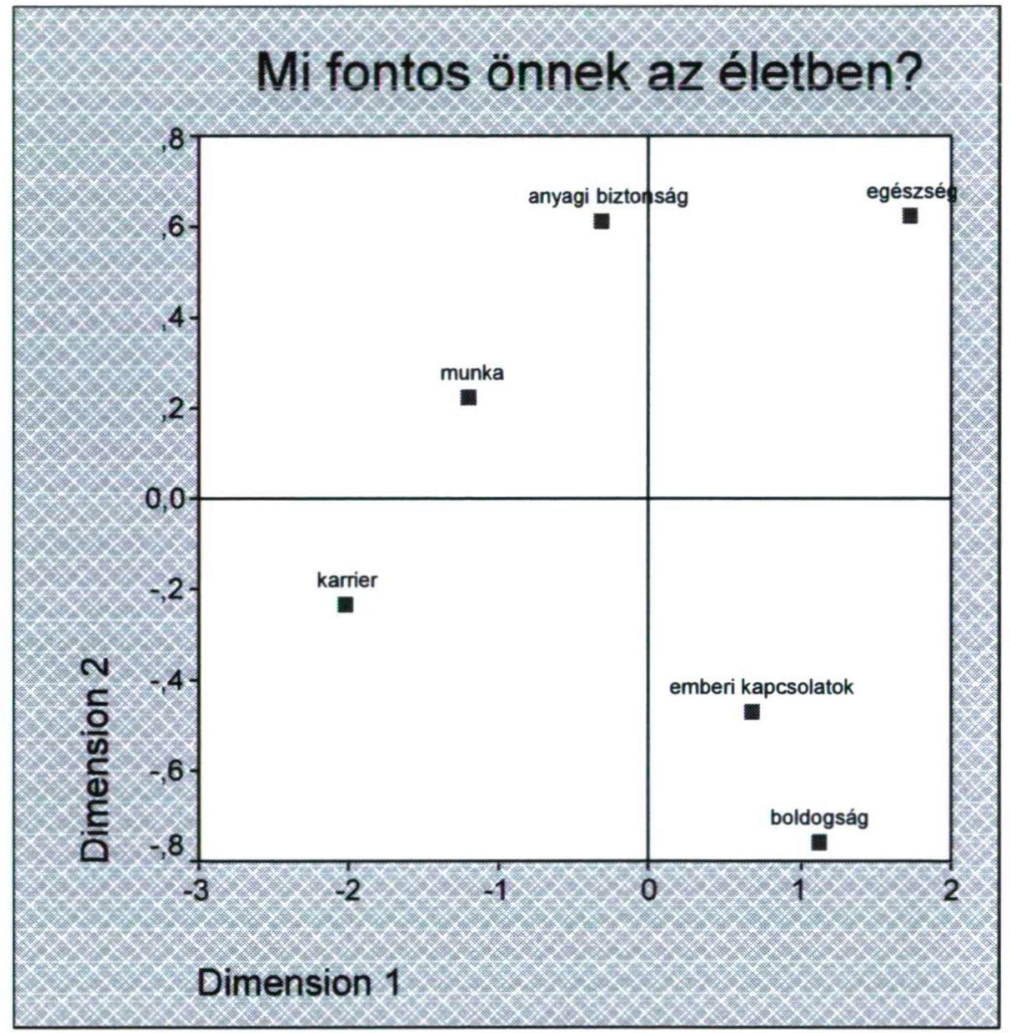

Forrás: Saját szerkesztés, 2012 
1. táblázat: Stimulus Coordinates (koordináták)

\begin{tabular}{|c|c|c|c|}
\hline & & \multicolumn{2}{|c|}{ Dimension } \\
\hline Stimulus Number & Stimulus Name & $\mathbf{1}$ & $\mathbf{2}$ \\
\hline 1. & MIFONT1 &, 6832 &,- 4684 \\
\hline 2. & MIFONT2 & 1,7280 &, 6232 \\
\hline 3. & MIFONT3 &,- 3145 &, 6139 \\
\hline 4. & MIFONT4 & $-2,0207$ &,- 2374 \\
\hline 5. & MIFONT5 & $-1,1993$ &, 2258 \\
\hline 6. & MIFONT6 & 1,1232 &,- 7572 \\
\hline
\end{tabular}

Forrás: Saját számítás, 2012

\section{KÖVETKEZTETÉSEK}

- Az életstílus kutatások hasznos segítséget nyújthatnak a célcsoport meghatározásnál, a termékek és márkák pozícionálásánál és a reklámüzenetek megfogalmazásánál.

- Az életstílus vizsgálatok statisztikai elemzésekor referenciacsoportokat határoztunk meg, amelynek kiemelkedő szerepe van a vásárlási döntések befolyásolásában. Az értékek egymáshoz viszonyított helyzetének kifejezésére a több dimenziós skálázás módszere bizonyult alkalmasnak.

- A tradíconális termékeket vásárlók csoportjainak vizsgálata során az értékítélet fontosabbnak tünik, mint más esetekben. Egy hatékony szegmentálás ötvözni képes a termékkategóriára sajátosan jellemzö fogyasztói dinamikát a szintén termék-specifikus motivációs dinamikával.

\section{FELHASZNÁLT IRODALOM}

Churcill, G. A. (2005): Marketing Research- Methodological Foundations $8^{\text {th }}$ Edition. New York The Dryden Press.

Maslow, A. (1997): Motivation and Personality. 3th Edition Harper and Row, Wiesbaden Anholt, S. (2002): Foreword to the Special Issue on Country Branding. Journal of Brand Management, Vol. 4. p. 14-25.

Baughn, C.C.-Yaprak, A. (1993): Mapping Country of Origin Research, Recent Developments and Emerging Avenues. In Product - Country Images. Impact and Role in International Marketing, Papadopoulos, N., Heslop, L.A. New York, International Business Press, p. 89-1 15.

Burt S. (2008): The Strategic Role of British Brands. 7th International Science Marketing Trends Congress, Venice

Guerro, L. - Colomer, J. - Guardia, D. - Xicol, J. (2004): Consumer Attitude Towards Brands. Food Quality and Preference, Vol. 11. No. 5. p. 387-395. 